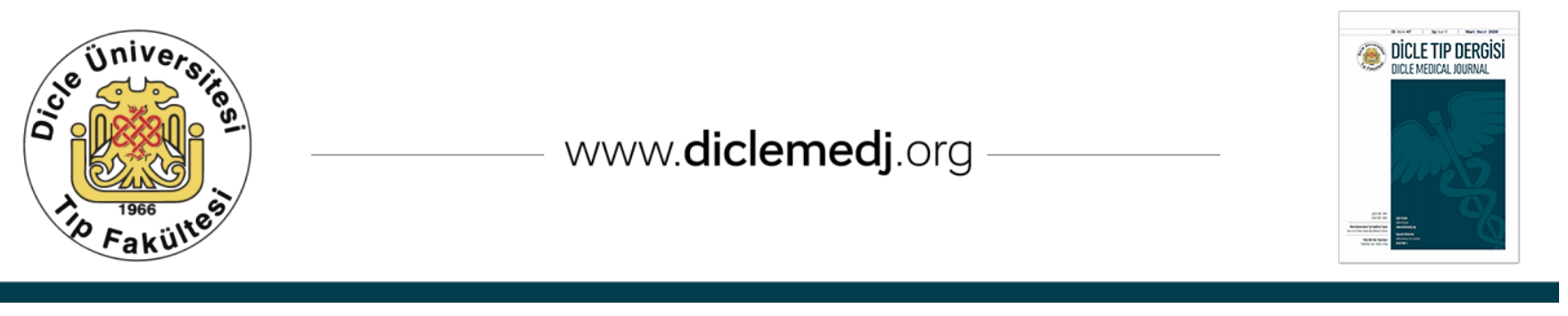

Original Article / Özgün Araştırma

\title{
Evaluation of Bone Marrow Reconversion in Healthy Adults with Knee MRI
}

\author{
Ayşe Serap Akgün1 \\ 1 İstanbul Medipol Üniversity, Faculty of Medicine, Department of Radiology Post code: 34214 Istanbul, Turkey
}

Received: 24.01.2020; Revised: 11.02.2020; Accepted: 17.02.2020

\begin{abstract}
Objective: Radiologists encounter bone marrow reconversion (BMR) frequently when evaluating knee magnetic resonance imaging (MRI). It is clinically important to know what these changes may be related to. The aim of this study to investigate the relationships between BMR at MRI with age, gender, body mass index (BMI), smoking and hemoglobin (hgb) levels in healthy adults.

Methods: In this prospective study, 107 healthy adults aged 26-62 years (55 women, 52 men ) were evaluated with knee MRI. The participants were divided according to the smoking histories as two groups: nonsmokers and heavy smokers. Red bone marrow changes examined by a radiologist in coronal T1-weighted sequences and classified into four groups according to their sizes. The levels of blood hgb of all patients were acquired and BMIs' were calculated. Statistical analyzes were performed with the SPSS 17.0 program.
\end{abstract}

Results: 24 (54.55\%) of 44 patients with BMR were nonsmokers and 20 (45.45\%) were heavy smokers. No statistically relation was found between marrow BMR and smoking history $(p>0,05)$. BMR was found to be more prevalent in obese female patients and over 41 years old patients $(p<0,001)$. A statistically significant relationship between the grades of BMR and hgb values was detected $(\mathrm{p}=0.013)$.

Conclusions: Whereas BMR is irrelevant with smoking, it is common especially in middle aged obese women. A significant relationship was found between the hgb values and the grades of BMR. These parameters should be kept in mind when BMR seen in MRI and these patients should be directed to laboratory assessment for anemia.

Keywords: Bone and Bones, Bone Marrow, Tobacco products, MRI.

DOI: 10.5798/dicletip.706056

Correspondence / Yazışma Adresi: Ayșe Serap Akgün, İstanbul Medipol Üniversity, Faculty of Medicine, Department of Radiology Post code: 34214

Istanbul, Turkey e-mail: drayserap80@gmail.com 


\section{Kemik İliği Rekonversiyonunun Sağlıklı Erişkinlerde Diz MRG ile Değerlendirilmesi}

$\ddot{0} \mathbf{z}$

Amaç: Radyologlar, diz manyetik rezonans görüntüleme (MRG) bulgularını değerlendirirken sıklıkla kemik iliği rekonversiyonu (KİR) ile karşılaşırlar. Bu değişikliklerin nelerle ilgili olabileceğini bilmek klinik olarak önemlidir. Bu çalışmanın amacı, sağlıklı erişsinlerde MRG'de KİR ile yaş, cinsiyet, vücut kitle indeksi (VKİ), sigara ve hemoglobin (hgb) düzeyleri arasındaki ilişkileri araştırmaktır.

Yöntemler: Bu prospektif çalışmada yaşları 26 ile 62 arasında değișen toplam 107 sağlıklı erişkin (55 kadın, 52 erkek) diz MRG ile değerlendirildi. Hastalar, sigara öykülerine göre sigara içmeyenler ve ağır içiciler olarak iki gruba ayrıldı. Kırmızı kemik iliği değișiklikleri radyolog tarafından T1 A koronal sekanslarda değerlendirildi ve boyutlarına göre 4 grupta sınıflandırıldı. Tüm hastaların eş zamanlı kan hgb seviyeleri ölçüldü ve VKİleri hesaplandı. İstatistiksel analizler SPSS 17.0 programı ile yapıldı.

Bulgular: Rekonversiyon görülen 44 hastanın 24'ü $(\% 54,55)$ sigara içmeyen, 20'si $(\% 45,45)$ ağır içicidir. Rekonversiyon ve sigara kullanımı arasında anlamlı ilişki bulunamadı $(\mathrm{p}>0,05)$. Rekonversiyon, obez kadınlarda ve 41 yaş üzeri hastalarda istatiksel anlamlı olarak daha çok saptandı $(\mathrm{p}<0,001)$. Rekonversiyonun derecesi arttıkça hgb değerlerinin anlamlı olarak düştüğü gözlendi ( $\mathrm{p}=0.013)$.

Sonuç: KİR, sigara ile ilişkisiz olup orta yaş ve üzeri obez kadın hastalarda daha sık görülmektedir. Hgb değerleri ile KİR gradeleri arasında önemli ilişki görülmüştür. MRG'lerinde KİR saptanan hastalarda bu parametreler akılda tutulmalı ve bu hastalar anemi için laboratuvar değerlendirmesine yönlendirilmelidir.

Anahtar kelimeler: Kemik ve kemikler, kemik iliği, tütün ürünleri, MRG.

\section{INTRODUCTION}

The normal bone marrow filling the medullary cavity in the middle of the bones consists of two different type and compositions: the red marrow contains hematopoietic stem cells with $40 \%$ fat, $\% 40$ water and $20 \%$ protein and the yellow bone marrow contains fat-producing and mesenchymal stem cells with $80 \%$ fat, $15 \%$ water and $5 \%$ protein ${ }^{1,2}$. Bone marrow conversion is called the transformation of active red bone marrow to inactive fatty bone marrow occurs in a certain order from the distal to the proximal to the extremities and from the appendix to the axial skeleton and be completed by approximately 25 years of age ${ }^{3-5}$. After this age, the red bone marrow is seen only in the axial skeleton, sternum, ribs, humerus and femur metaphyses. In cases where hematopoietic bone marrow fails to meet the hematopoiesis requirement, the red bone marrow replaces the yellow bone marrow and called bone marrow reconversion (BMR). BMR can occur not always in pathologic and can be seen in different conditions such smokers, highperformance athletes, anemic individuals, bone marrow replacement diseases, bone marrowstimulating drugs, and obese patients ${ }^{3,4,6,7}$. BMR can be seen noninvasively in daily sequences of magnetic resonance (MR) imaging and radiologists must know the signal characteristics of this physiological process and avoid misdiagnosis. In the literatüre results about the BMR and related physiological causes in knee MRI are still confusing because of conflicting results. In this study we aimed to evaluate factors associated with BMR of the knee in adults without known bone marrow disorders with MRI. We investigated the relationships between BMR with age, gender, body mass index (BMI), smoking and hemoblobin (hgb) levels.

\section{METHODS}

This study follows the Declaration of Helsinki. Patients who visited to radiology department to 
undergo knee MRI for assesing ligamentous or meniscal abnormalities after asking smoking history had voluntarily agreed to the study and gave their informed consent. All study persons have received and signed patient education form before MRI. The study was initiated following approval granted by the local ethics committee. (date of approval: 30.10.2018, approval no: 10840098-604.01.01-E.47624). According to a study published by Gonzalez et al. the sample size was calculated and the minimum subject number was found 47 in each group which would be necessary to detect that difference at the $5 \%$ level $(a=0.05)$ with an $80 \%$ chance8 $(b=0.2)$. Between October 2018 and December 2018, a total of 107 patients, 55 women and 52 men aged 26-62 years underwent knee MRI were evaluated prospectively. Exclusion criteria were to be younger than 25 years (to be certain to have enough adult yellow bone marrow), history of trauma and having marrow edema, history of bone marrow disorders or hematopoietic disease or having chemotherapy, radiotherapy or steroid treatment and being intermediate smoker who currently smoked but had not heavy smoking category. After performing knee MRI, all the cases were requested simultaneously to take sample of blood tests and to measure the hgb values. According to smoking histories the participants were divided as two groups: nonsmokers and heavy smokers. Nonsmokers who had no smoked or had quit smoking more than 1 year at the time of MR imaging. Heavy smokers who consumed one pack (20 cigarettes) or more per day or quit smoking within the previous year. Intermittent smokers who currently smoked but didn't reach to heavy smoking class' level didn't include the study. The patients' body mass index (BMI) was calculated as the weight $(\mathrm{kg})$ divided by the square of height $(\mathrm{m})$. BMIs $\geq 30.0 \mathrm{~kg} / \mathrm{m} 2$ were accepted as obese according to World Health Organization (WHO) definitions ${ }^{9}$. Anemia was accepted $\leq 12.0 \mathrm{~g} / \mathrm{dL}$ in women and $\leq 13.0 \mathrm{~g} / \mathrm{dL}$ in men according to WHO definition ${ }^{10}$.

All MRI scans were performed on a 1,5 Tesla scanner (MAGNETOM, Siemens, Erlangen, Germany) with the knee extended. Rutine knee MRI protocol of our department were included axial proton density fat-saturated, coronal and sagittal T1-weighted (T1W), sagittal proton density fat-saturated (PDFS) sequences. Coronal T1W (TR 471msec, TE $9.4 \mathrm{msec}$, FOV: $160 \mathrm{~mm}$, matrix: $205 \times 306 \mathrm{~cm}$, slice thickness: $4 \mathrm{~mm}$ ) and sagittal PDFS ( TR $3540 \mathrm{~ms}$, TE 31 ms, FOV: $160 \mathrm{~mm}$ matrix: $224 \times 320 \mathrm{~cm}$ slice thickness:3 mm) images were used to determine the signal alterations.

The hematopoietic bone marrow changes in the distal femoral and proximal tibial metaphyses and apperance of red marrow were examined by a radiologist who was blind to patients' smoking histories in coronal $\mathrm{T} 1 \mathrm{~W}$ sequences and classified into groups according to their isohyperintensity sizes relative to the neighboring muscle tissue described by Lang et al : Grade 0: uniform high signal (without any signal change), grade 1: focal,puntate, grade 2: multifocal without confluence, grade 3: patchy with confluence and grade 4: complete11 (Figure 1).

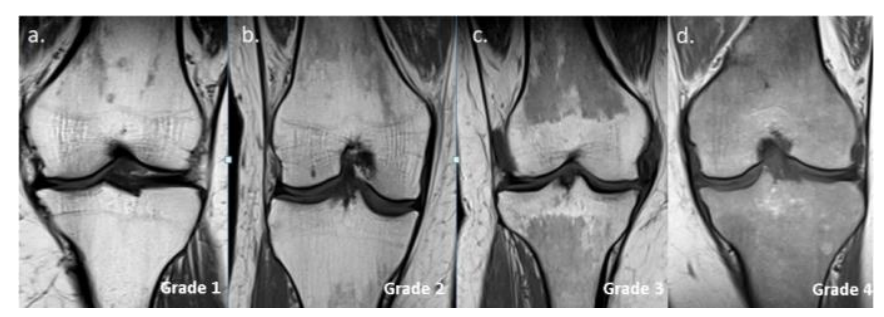

Figure 1. Coronal T1-weighted MR images demonstrating sequantial examples of red bone marrow reconversion; a. Grade 1 (focal, puntate red marrow areas in the distal femur) b. Grade 2 (multifocal without confluent red marrow areas in the distal femur and proximal tibia) c. Grade 3 (patchy with confluent red marrow areas in the distal femur and proximal tibia) d. Grade 4 ( with complete red marrow areas in the distal femoral and proximal tibial metaphyses).

All the signal intensities confirmed as isohypointens in proton density fat-saturated 
sequences relative to the neighboring muscle tissue. To assess the reliability of the examinations, the same radiologist checked all the patients one month after the first evaluation.

Statistical analyzes were performed with the SPSS 17.0 program. For the statistical evaluation of proportional differences chi-square test and for the comparison of quantitative data nonparametric Mann-Whitney $U$ test and Kruskal- Wallis tests were performed. $\mathrm{P}<0.05$ accepted as statistically significant.

\section{RESULTS}

The study included 107 patients [55 women $(51.40 \%)$ and 52 men (48.60\%)] with an average of 41.73 years (range, 26 to 62 years). According to the smoking histories the patients were divided as two groups: 54 were nonsmokers and 53 were heavy smokers (Table 1). Forty-four of 107 patients (41.12\%) had BMR. Table 1 showed the demographic data of the cases. Of the 44 patients who had BMR, 24 (54.55\%) were nonsmokers and 20 (45.45\%) were heavy smokers. No statistically significant association was found between BMR and heavy smoking $(p>0,05)$. The average smoking of 20 patients who smoke and have BMR was 1 pack/20 years. However there was no correlation between the package/ year and the reconversion grades $(p>0,05)$.

Table 1. The demographic data of the cases.

\begin{tabular}{|l|l|l|l|}
\hline \multirow{2}{*}{ Group } & Nonsmoker & $\mathbf{n}$ & $\%$ \\
\cline { 2 - 4 } & Heavy smoker & 54 & $(50.47)$ \\
\hline \multirow{3}{*}{ Gender } & Male & 53 & $(49.53)$ \\
\cline { 2 - 4 } & Female & 52 & $(48.60)$ \\
\hline \multirow{3}{*}{ Obesity } & Absent & 55 & $(51.40)$ \\
\cline { 2 - 4 } & Present & 68 & $(63.55)$ \\
\hline \multirow{3}{*}{ Reconversion } & Absent & 39 & $(36.45)$ \\
\cline { 2 - 4 } & Present & 63 & $(58.88)$ \\
\hline
\end{tabular}

BMR was seen 38 of the 55 women (\%86.36) and 6 of 52 men (\%13.64) and was significantly higher in women $(p<0,001)$. A statistically significant difference was found in gender distribution of grading reconversion $(p<0,05)$. Among female cases, there were 16 grade 1,9 grade 2, 11 grade 3 and 2 grade 4 cases and in male cases there were 5 grade 1 and 1 grade 2 . No male cases were found in grade 3 and grade 4 groups.

Evidence of BMR was observed in thirty of 44 patients older than mean age of 41 years old. BMR was also shown in $61.36 \%$ of the obese population (BMIs' were $\geq 30$ ), while reconversion was seen in $19.05 \%$ of the nonobese subjects. Of the 39 obese patients ( $36.45 \%) 8$ of them were men $(20.51 \%)$ and 31 of them were women $(79.49 \%)(p<0.05)$. Consequently BMR was statistically higher in obese women and patients over 41 years of age $(\mathrm{p}<0.05)$ (Table 2).

Table 2. Comparison of BMR with age, gender and obesity.

\begin{tabular}{|c|c|c|c|c|c|c|}
\hline \multirow{3}{*}{ Group } & & \multicolumn{4}{|c|}{ BMR } & \multirow{3}{*}{$\mathbf{p}$} \\
\hline & & \multicolumn{2}{|c|}{ Absent } & \multicolumn{2}{|c|}{ Present } & \\
\hline & & $n$ & $\%$ & $\mathrm{n}$ & $\%$ & \\
\hline \multirow{2}{*}{ Age } & $<41$ & 30 & (47.62) & 14 & (31.82) & \multirow{2}{*}{$<0,001$} \\
\hline & $\geq 41$ & 33 & $(52.38)$ & 30 & $(68.82)$ & \\
\hline \multirow{2}{*}{ Gender } & Male & 46 & (73.02) & 6 & $(13.64)$ & \multirow{2}{*}{$<0,001$} \\
\hline & Female & 17 & (26.98) & 38 & $(86.36)$ & \\
\hline \multirow{2}{*}{ Obesity } & Absent & 51 & (80.95) & 17 & $(38.64)$ & \multirow{2}{*}{$<0,001$} \\
\hline & Present & 12 & (19.05) & 27 & (61.36) & \\
\hline
\end{tabular}

BMR=Bone Marrow Reconversion

The mean hgb values in female patients was $12.6 \pm 1.71 \mathrm{~g} / \mathrm{dL}$ and in male patients was $15.4 \pm 0.46 \mathrm{~g} / \mathrm{dL}$. Nine of 44 patients with BMR were anemic (20.45\%) and all of them were women. None of the male patients had anemia. When the relationship between BMR and anemia was examined, no significant 
Table 3. Age, BMI and Hgb values according to BMR.

\begin{tabular}{|c|c|c|c|c|c|c|c|c|c|c|c|c|c|}
\hline & \multicolumn{12}{|l|}{ Grade } & \multirow{3}{*}{$p$} \\
\hline & \multicolumn{3}{|c|}{ Grade $1(n=21)$} & \multicolumn{3}{|c|}{ Grade $2(n=10)$} & \multicolumn{3}{|c|}{ Grade $3(n=11)$} & \multicolumn{3}{|c|}{ Grade $4(n=2)$} & \\
\hline & Mean & s.s. & Median & Mean & s.s. & Median & Mean & s.s. & Median & Mean & s.s. & Median & \\
\hline Age & 44.86 & \pm 9.65 & 45.00 & 43.40 & \pm 7.47 & 45.50 & 41.36 & \pm 9.20 & 40.00 & 51.00 & \pm 7.07 & 51.00 & 0.509 \\
\hline $\mathrm{BMI}$ & 28.97 & \pm 4.36 & 29.10 & 32.36 & \pm 4.23 & 32.90 & 33.66 & \pm 5.59 & 33.20 & 31.00 & \pm 1.41 & 31.00 & 0.060 \\
\hline $\mathrm{Hgb}(\mathrm{g} / \mathrm{dL})$ & 13.8 & \pm 1.89 & 14.3 & \begin{tabular}{|l|}
12.9 \\
\end{tabular} & \pm .97 & 12.9 & \begin{tabular}{|l|}
12.1 \\
\end{tabular} & \pm 1.10 & 12.2 & 9.2 & \pm 2.55 & 9.2 & 0.013 \\
\hline
\end{tabular}

BMI=Body Mass Index Hgb:Hemoglobin

relationship was found between them ( $p>0.05$ ). Although there was no statistical relationship between the presence of anemia and BMR, there was a significant correlation between grade of BMR and hgb values $(p=0.013)$. The mean values of hb was $13.8 \pm 1.89$ for grade 1 , $12.9 \pm 0.97$ for grade $2,12.1 \pm 1.10$ for grade 3 and was $9.2 \pm 2.55$ for grade 4 BMR (Table 3 ).

There were only two patients for statistically analysis of grade 4 (Figure 2,3).

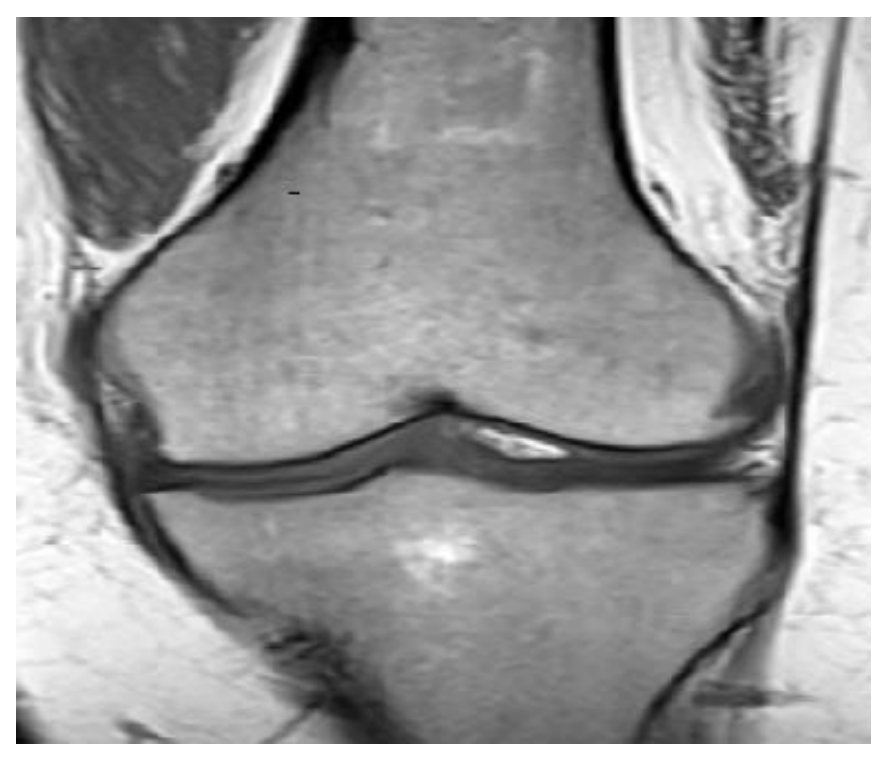

Figure 2. Coronal T1-weighted MRI of the knee in a 56-yearold nonsmoker woman with grade 4 bone marrow reconversion. (BMI:32, Hgb level:7.4 g/dL).

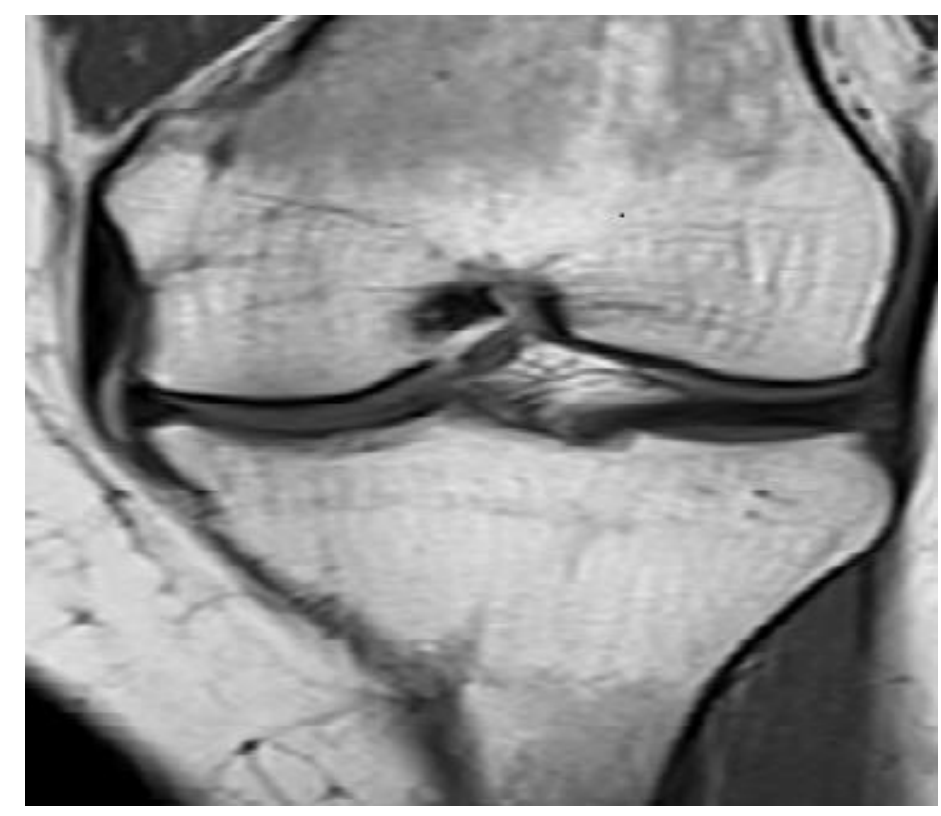

Figure 3. Coronal T1-weighted MRI of the knee in a 45-yearold heavy smoker woman with grade 2 bone marrow reconversion. (BMI:35.1, Hgb level:12.8 g/dL).

\section{DISCUSSION}

In this study conducted with healthy individuals, the incidence of BMR was $41.12 \%$ and it was shown so frequently that we encountered in daily routine so as not to underestimate. Therefore, especially radiologists should know BMR and related physiological and pathological conditions in order not to overdiagnose and be able to guide clinicians correctly.

MRI is the unique imaging modality allowing to detect bone marrow changes with high soft 
tissue and anatomical resolution without contrast agent enjection. The MRI signal changes according to the amount of red and yellow marrow and it is necessary to be aware of abnormal conversion and reconversion patterns. BMR appears as hypointens in T1W images relative to the bone tissue and isohyperintens relative to the muscle tissue. In fatsuppresed images BMR appears iso-hypointens relative to the muscle tissue where as pathological conditions mostly show more hyperintensity than the muscle tissue ${ }^{12,13}$.

For the first time in 1989, Deutsch showed that BMR was more common in healthy obese women who received in routine knee MRI in 10 asymptomatic patients ${ }^{6}$. Poulton et al. tried to investigate the frequency of BMR around the knee to age, gender, obesity and smoking in 59 patients. However they did not find any association between the weight or gender with BMR such as in the study of Arslan's et al with 140 nonsmoking healthy subjects ${ }^{7,14}$. In our study 38 of 44 patients with BMR were female and it was statistically significant $(\mathrm{p}<0.05)$. Obesity rate was also statistically significant in patients with BMR $(\mathrm{p}<0.05)$. Although Poulton et al. observed BMR in younger than 39 years, our results showed that BMR was found to be more prevalent in patients older than 41 years old7. Wilson et al. observed BMR on MR images of 199 asymptomatic patients. They also found the association between age, gender, obesity and BMR15. They showed BMR was more common in obese female patients with aged 3060 years with a peak prevalence occurring in the 50s. In our study, only 14 of 38 patients with BMR were aged 50 and over and only 7 patients were postmenopausal. In accordance with the other researchers we can explain this result by the increased demand for hematopoiesis by the menstruation.

Although Poulton et al, Wilson et al and Budde et al showed that smoking can lead dysmyelopoiesis and BMR changes, we found no statistically association between smoking and

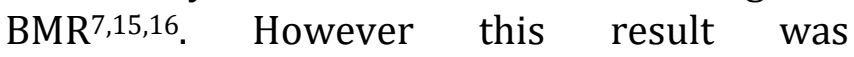
disappointing and difficult to explain, Gonzales et al find no association between smoking and BMR as we $\mathrm{do}^{8}$. May be this conclusion can be explained by the small size of the study population.

In the current study, we did not find an association between anemy and BMR but showed significant correlation between reconversion grades and hgb values $(\mathrm{p}<0.05)$. According to this; there was a statistically significant low hgb concentration in patients with grade $1(\mathrm{p}<0.05)$. It was observed that hgb values decreased with increasing grade of BMR and two patients with grade 4 pattern were women with an average hgb value of $9.2 \mathrm{~g} / \mathrm{dL}$. These women with grade 4 BMR changes were obese and anemic but nonsmoker.The cause of anemia is multifactorial and the mechanism of BMR is complex. Therefore, the hgb values below a certain value may be a necessary in order to see the BMR visible radiologically.

Our study has several limitations. First the sample size was not much enough, there may be some bias. Especially we do not detect men patients with grade 3 and grade 4 BMR. In our sample, there were only 2 patients with severe anemia and grade 4 BMR. Although this supports our hypothesis, BMR should be investigated in larger series with severe anemia. Second, the evaluation of the red bone marrow areas had no standardization and in previous studies BMR measurement was performed with different qualitative methods.

\section{CONCLUSIONS}

In conclusion, while reporting knee MRI in daily routine, bone marrow abnormalities are so frequent. Whereas BMR is irrelevant with smoking, it is common especially in middle aged obese women. A significant relationship was found between hgb values and the reconversion grades. These parameters should be kept in 
mind when BMR seen in MRI and these patients should be directed to laboratory assessment for anemia.

Ethics Committee Approval: The study was initiated following approval granted by the local ethics committee. (date of approval: 30.10.2018, approval no: 10840098-604.01.01E.47624).

Declaration of Conflicting Interests: The authors declare that they have no conflict of interest.

Financial Disclosure: No financial support was received.

\section{REFERENCES}

1. D.C. Karampinos, S. Ruschke, M. Dieckmeyer, et al. Quantitative MRI and spectroscopy of bone marrow. J. Magn. Reson. Imaging 2018; 47: 33253.

2. Vogler JB, Murphy WA. Bone marrow imaging. Radiology 1988; 168: 679-93.

3. Kung JW, Yablon CM, Eisenberg RL. Bone marrow signal alteration in the extremities. AJR Am J Roentgenol 2011; 196: W492-510.

4. Tokgoz N. Neoplazik olmayan Kemik İliği Bozuklukları. Trd Sem 2016; 4: 540-54.

5. Starr AM, Wessely MA, Albastaki U, PierreJerome C, Kettner NW. Bone marrow edema: pathophysiology, differential diagnosis, and imaging. Acta Radiol 2008; 49: 771-86.

6. Deutsch AL, Mink JH, Rosenfelt FP, Waxman AD. Incidental detection of hematopoietic hyperplasia on routine knee MR imaging. Am J Roentgenol 1989; 152: 333-6.

7. Poulton TB, Murphy WD, Duerk JL, Chapek CC, Feiglin DH: Bone marrow reconversion in adults who are smokers: MR imaging findings. Am J Roentgenol 1993; 161: 1217-21.
8. Gonzalez FM, Mitchell J, Monfred E, Anguh T, Mulligan M. Knee MRI patterns of bone marrow reconversion and relationship to anemia. Acta Radiologica 2015; 57: 964-70.

9. World Health Organization Obesity: preventing and managing the global epidemic. World Health Organ Tech Rep Sep 2000; 894:1253.

10. World Health Organization. Haemoglobin concentrations for the diagnosis of anemia and assessment of severity. Vitamin and Mineral Nutrition Information System. Geneva: WHO, 2011. Available at: http www.who.int/vmnis/indicators/haemoglobin. pdf (accessed 1 July 2015).

11. Lang P, Fritz $R$, Majumdar $S$, et al. Hematopoietic bone marrow in the adult knee: spin-echo and opposed-phase gradient-echo MR imaging. Skeletal Radiol 1993; 22: 95-103.

12. Malkiewicz A, Dziedzic M. Bone marrow reconversion - imaging of physiological changes in bone marrow. Pol J Radiol 2012; 77: 45-50.

13. Zimmer WD, Berquist TH, McLeod RAA, et al. Bone tumors: magnetic resonance imaging versus computed tomography. Radiology 1985; 155: 709-11.

14. Arslan G, Ozmen E, Soyturk M. MRI of Residual Red Bone Marrow in the Distal Femur of Healthy Subjects. Pol J Radiol 2015; 80: 00-4.

15. Wilson AJ, Hodge JC, Pilgram TK, Kang EH, Murphy WA. Prevalence of red marrow around the knee joint in adults as demonstrated on magnetic resonance imaging. Acad Radiol 1996; 3: $550-5$.

16. Budde R, Schaefer HE. Smokers' dysmyelopoiesis: bone marrow alterations associated with cigarette smoking. Pathol Res Pract 1989; 185: 347-35. 